\title{
Role of Phytogenic Feed Additives in Swine Production- A Review
}

\author{
M V A N Suryanarayana ${ }^{1 *}$ and S. Durga ${ }^{2}$ \\ ${ }^{1}$ Professor \& Head (Animal Nutrition), Department of Livestock Farm Complex, College of Veterinary Science, Sri \\ Venkateswara Veterinary University, Tirupati-517502 (Andhra Pradesh) INDIA \\ ${ }^{2}$ Teaching Assistant, Department of Livestock Farm Complex, College of Veterinary Science, Sri Venkateswara Veterinary \\ University, Tirupati-517502 (Andhra Pradesh) INDIA
}

\begin{abstract}
Continuous research is being carried out to attain higher productivity with the available resources since several decades. Feed additives comprising of probiotics, prebiotics, acidifiers, immune modulators, buffering agents, ionophores etc. though are in vogue, in addition to antibiotic growth promoters(AGP), advancement is being aspired through the way of herbs and their products which are called as Phytogenic feed Additives (PFA) or simply Phytobiotics. PFA are said to be having positive effects in improving the performance of poultry and swine. Many reports say that PFA increase the dry matter intake probably due to an increased palatability of the feed.PFA is said to have anti microbial and anti oxidant properties. In addition, PFA have shown to improve the endogenous enzyme secretion, stimulation of appetite, improving the digestibility and absorption of nutrients and also promote the proliferation of beneficial bacteria like Lactobacillus spp. A ban on the use of AGP leads to explore the use of herbs and their products like extracts and residues. Herbal residues are the left over's remained after the active principle is extracted. Reports say that extraction efficiency (\%) ranges from 88-97 for different methods. Some of the residues showed considerable anti bacterial property at $2 \%$ levels during the Minimum Inhibitory Concentration tests. The use of PFA is restricted to commercial preparations and results are available only for these works, there needs a systemic approach to explain about the function of these PFA in terms of type and dose of each additive. However long term studies will be of added advantage proving the efficacy of these PFA,their safety for animal health and their availability widely in nature. The aim of this review is to explore and explain the multifaceted properties of PFA in terms of elimination of gut pathogens improving the digestibility and palatability and thus enhancing the overall production of the animal.
\end{abstract}

Keywords - Feed additives, PFA, performance, pathogen inhibition, nutrient digestibility.

\section{INTRODUCTION}

Any nutrient fed to the livestock is meant for its productivity and the accountability for this nutrient is fulfilled only when it is used to the maximum extent. Proteins and energy, the major nutrients are of critically important and these provide energy to the livestock on metabolism. But there are certain non-nutrient substances used in animal nutrition for getting the better quality of feed, better quality livestock products, for better availability of nutrients in the gut, and also for improving the gut health. Feed additives are the non-nutrient substances which come under this category. Common feed additives used in animal diets include probiotics, prebiotics, immune modulators, antimicrobials, anti oxidants, enzymes, $\mathrm{pH}$ control agents, flavonoids in addition to antibiotic feed supplements

There is increasing pressure for livestock producers to minimize the use of antibiotics as growth promoters in food animals. There is a ban on the use of most of the antibiotic feed additives within the European Union in 1999, a complete ban enforced in 2006, due to a speculated risk of generating antibiotic-resistance in pathogenic bacteria.

\section{Some discussion on other feed additives}

Prebiotics have been described as non-digestible oligosaccharides which selectively stimulate the growth of favourable species of bacteria in the gut, thereby benefitting the host. Because they are not digested and absorbed by the pig, they provide readily available substrates for the normal bacteria to grow. Fructooligosaccharides (FOS), Mono-oligosaccharides (MOS) and inulin are the best examples that have been used as prebiotics.

Probiotics are live microbials supplemented in pig diets that can beneficially affect the host animal by improving the microbial balance in the gut.Probiotics commonly used includeLactobacillus acidophilus, Enterococci faecium, Bacillus species, Bifidobacteriumbifidum, and the yeast Saccharomyces cerevisiae. As feed additives, they are supplemented in diets to improve the balanceof bacteria in the gut. 
The proposed benefits from probiotics are improved digestion, stimulation of gastrointestinal immunity and increased resistance to infectious diseases of the gut. Probioticsalso changes the permeability of the mucous membrane and increase the nutrient uptake and thus improve the growth performance.

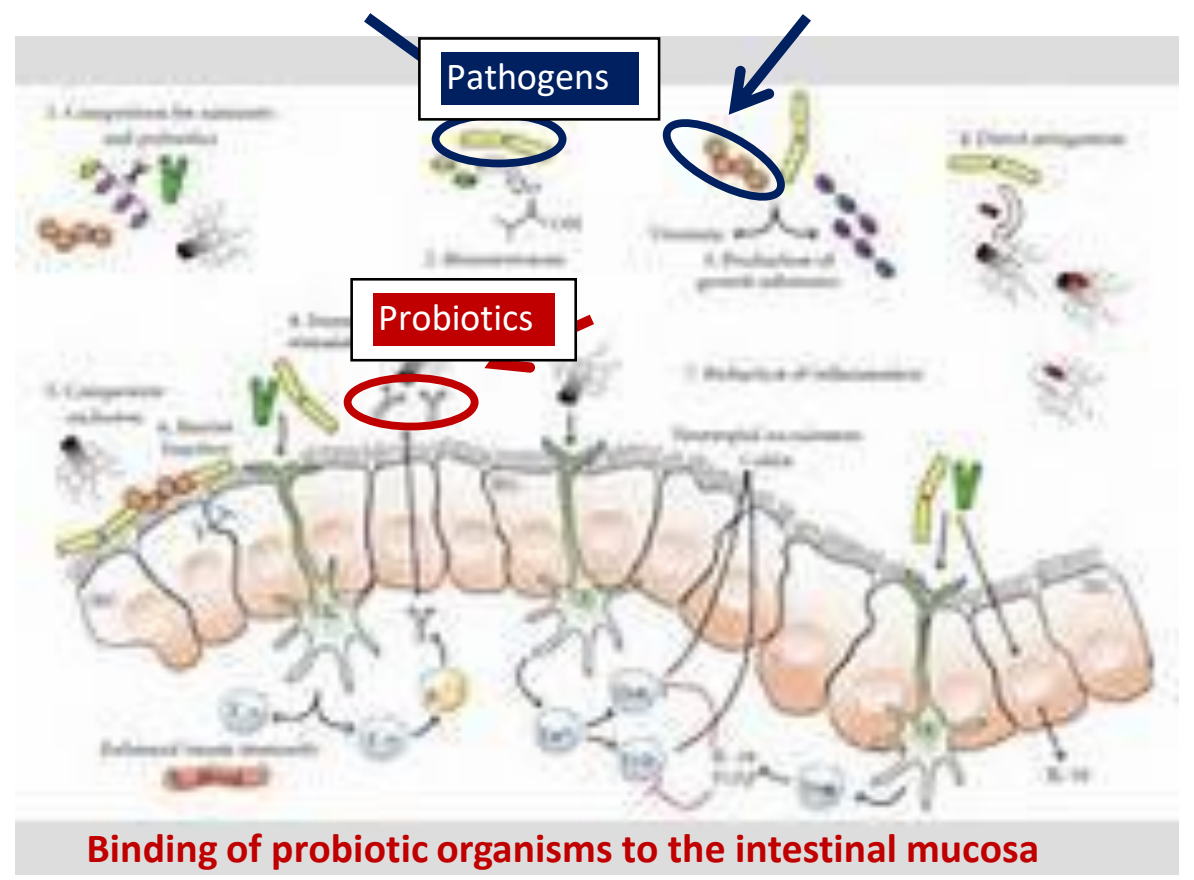

Anotherimportant feed additivesare the antibiotic growth promoters (AGP).These are the substances which are produced by the living organisms (molds, bacteria, fungi or green plants) and which have bacteriostatic /bacteriocidal properties. In addition to their feed addition as growth promoters, antibiotics are used as nutritional stimulants to promote better feed efficiency in ruminants and swine and to increase the egg production, hatchability and shell quality in poultry. They are also added to the feed in substantially higher quantities to remedy pathological conditions. Since there is a ban on the use of AGP in the farm animals to improve the productivity and health status by the European Union and US, the use of other feed additives have come into force.

Other feed additives include those which influence feed stability, those which modify animal growth, which feed efficiency, metabolism and performance and those which modify consumer acceptance. Antifungals, antioxidants, pellet binders, acidifiersfeed flavours, buffers, immune modulators, xanthophylls etc all come under these categories. In spite of very good results obtained using these additives, they are still not comparable to those obtained using antibiotic growth promoters and research is still very actively looking for new alternatives to combat the increased potential for bacterial disease development in growing pigs especially under conditions of average management quality.All these additives either improve the keeping quality of the feed or increase the feed intake and most of them have no role in the nutrient utilization from the feed in the gut. For the nutrients to be utilized to the maximum they have to be attached to the gut mucosa for absorption and utilization.But this sometimes gets minimized due to the presence of pathogenic organisms which compete with the nutrients for absorption cites in the gut mucosa. In this process, some of the nutrients will be eliminated from the gut due to lack of sites. Hence there should be some additive which eliminates the pathogens from the gut and this is to say that the additive should have antibacterial property. Antibiotic feed additives belong to this category. With the introduction of Aureomycin in 1949 as a growth promoter, sub-therapeutic dosage of antibiotics in animal feed has been generalized all over the world and has produced important benefits in productive performance and in the prevention of pathologic processes (Anderson et al., 1999). However after five decades of usage, concerns about bacterial resistance have become an important issue. Since there is a ban on the use of these antibiotics, alternates in the form of Phytogenic feed additives are being explored.

\section{What are Phytogenic feed additives}

Phytogenic feed additives (often also called 'phytobiotics' or 'botanicals') are commonly defined as plant-derived compounds incorporated into diets to improve the productivity of livestock through amelioration of feed properties, promotion of the animals' production performance, as well as improving quality of food derived from those animals.

Herbs, their residues and plant extracts (PE) are one of the oldest additives used by mankind. However during the $20^{\text {th }}$ century, they are left apart because of the production of synthetic drugs. Recently doubts about 
safety of some synthetic drugs, especially antibiotics, have allowed the growth of new interest on the so-called natural products i.e., herbs and plant extracts. These are termed as Phytogenic feed additives(often also called 'phytobiotics' or 'botanicals') which are commonly defined as plantderived compounds incorporated into diets to improve productivity of livestock through amelioration of feed properties, promotion of the animals' production performance, as well as improving quality of food derived from those animals.
Whole herbs contain many active principles used to treat diseases and relieve symptoms. Herbal medicine (botanical medicine), uses the plant's seeds, berries, roots, leaves, bark or flowers for medicinal purposes. Many factors like the type of environment in which the plant grows, the harvesting method of the herb and the way in which the herbal plant is processed influence the efficiency of an active principle. Maceration with solvents like water, alcohol and other solvents will also affect the efficiency of an active principle to work.

\section{Schematic diagram on the various functions of phytogenic feed additives}

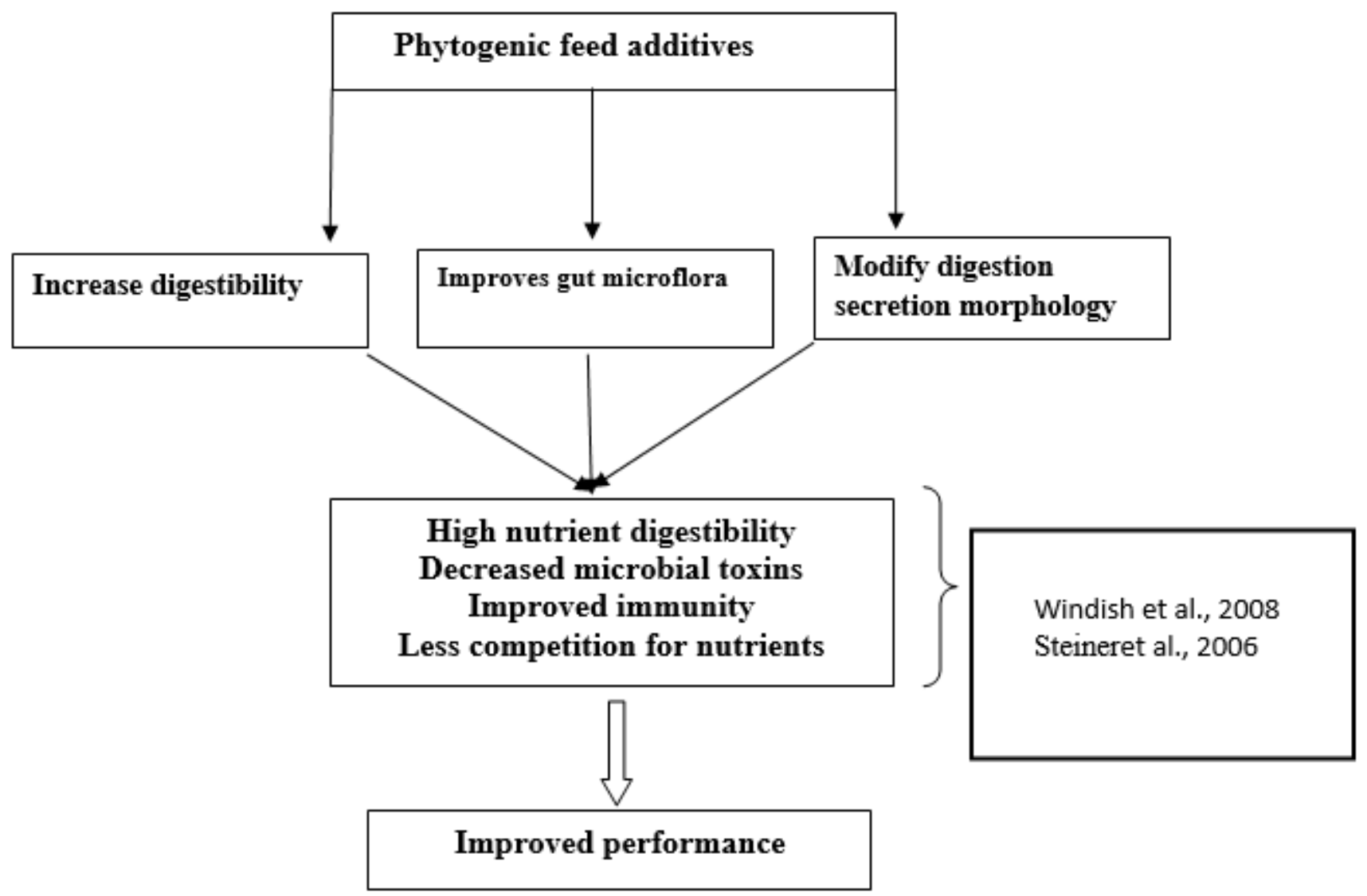

Probable functions of Phytogenic feed additives

These feed additives explored after a ban on certain additives is said to have antimicrobial (Guo et al, 2004 a), antioxidant (Hahemi et al, 2009 a), anti-stress (Chattopadhyaya et al,2005), gut flora multiplication (Hahemi et al, 2009 b)and immune enhancement (Guo et al, 2004 b) and over and above feed intake is increased. Photogenic feed additives also comprises of a wide variety of herbal residues, spices and products derived thereof. The mode of action of plant active substances include improvement of the endogenous enzymes secretion, stimulation of appetite, improving the digestibility and absorption of nutrients, promote proliferation of beneficial bacteria like Lactobacillus species in the gut.

\section{Anti microbial property}

Many reports say that these feed additives have antibacterial /anti microbial property which is depicted by the inhibition of many pathogenic bacteria in the gut (Chizzola et al, 2005; Newman et al, 2000; Cowman 1999;Baratta et al, 1999; Namkung et al, 2004). It was also reported that these improve the post weaning performance in pigs (Sulabo et al., 2010). Anti microbial effect is due to the elimination of pathogenic bacteria in the gut and thus making the nutrients more available to the animals and thus improves the performance. This property is mainly attributed to the presence of essential oils in the medicinal plants. Oregano and Thyme are the main essential oils which gained interest in this regard. 
In general, phytogenic feed additives have a strong antibacterial and to some extent antifungal properties. They inhibit the growth of Escherichia coli, Proteus sp, Staphylococci, Streptococci and Salmonella (Aruomaet al., 1996; Benencia and Courreges, 2000; Garcia et al., 2003) which otherwise compete with the host for nutrients.

The antimicrobial property was attributed to the hydrophobicity (Newbold et al., 2004) of plant extracts which facilitates their union to the bacterial surface inducing unstabilization (Tsuchiya et al., 1996; Zhang and Lewis, 1997) or the inactivation of different molecules of the bacteria such as enzymes or receptors through their union to the specific site(Mohammadi et al 2015 a \& b).

Residues of Ginger, Emblica and Turmeric were used in the swine rations (Suryanarayana, 2010) and has reported maximum inhibitory effect on pathogenic bacteria in the gut was shown by Ginger followed by Turmeric and Emblica. The antibacterial effect in gut pathogens was in the order of ginger $>$ turmeric $>$ amla.

These products are used in animal production as alternatives to AGP because of their antimicrobial properties. However, many other different effects have been reported such as changes in immune function (Boyakaet al., 2001), enzyme stimulation (Platel and Srivasan, 2000), antiparasitic (Force et al., 2000), antifungal (Mahmoud, 1994), antiviral effects (Aruomaet al., 1996; Benencia and Courreges, 2000; Garcia et al., 2003), anti-toxigenic activity (Sakagamiet al., 2001) and antioxidant activity (Dorman et al.,2000 ; Teissedre and Waterhouse, 2000). Concerning digestive function, they have important effects upon secretions and motility of the stomach and intestine. Given the enzymatic limitation of the piglet at weaning and also the limited ability of the pigs to digest dietary fibre, these products may be beneficial in improving the digestive capacity of pigs.

Emblicaofficinalis

(Synonym,

Phyllanthusemblica) has been known to have antioxidant, hepatoprotective and immunomodulation effects (Bandyopadhyayet al., 2000; Sai Ram et al., 2002).

Ginger (Gingeberisofficinale) has strong antibacterial and to some extent antifungal properties. In vitro studies have shown that active constituents of ginger inhibit multiplication of bacteria in colon. These bacteria ferment undigested carbohydrates causing flatulence. It inhibits the growth of Escherichia coli, Proteus spp, Staphylococci, Streptococci and Salmonella. The ginger extract has antimicrobial action at levels equivalent to $2000 \mathrm{mg} / \mathrm{ml}$ of the spice. Ginger inhibits aspergillus, a fungus known for production of aflatoxin, a carcinogen. Fresh ginger juice showed inhibitory action against Asperigillu sniger, S.cerevisiae, Mycodermaspp..and $L$. acidophilus at 4,10,12 and 14\% respectively, at ambient temperatures, respectively (Windischet al., 2008)

Turmeric (Curcuma longa) is a well-known indigenous herbal medicine. It's major constituents, curcumin, various curcuminoids, curcuma oil particularly dl-ar-turmerone-exhibit a wide range of biological activities like anti-bacterial (Windischet al., 2008), anti-inflammatory, hypolipidemic, hepatoprotective, lipoxygenase, cycloxygenase, protease inhibitory effects, besides being effective active oxygen scavengers and lipid peroxidase inhibitors.

Antibacterial activity (Inhibition zone, mm) of herbal residues (Suryanarayana, 2010)

\begin{tabular}{|c|c|c|c|c|c|c|c|c|}
\hline $\begin{array}{l}\text { Herbal } \\
\text { residues }\end{array}$ & $\begin{array}{c}\text { Escherich } \\
\text { ia coli }^{*}\end{array}$ & $\begin{array}{l}\text { Staphylococ } \\
\text { cus aureus* }\end{array}$ & $\begin{array}{c}\text { Salmonella } \\
\text { typhimuriu } \\
m^{*}\end{array}$ & $\begin{array}{c}\text { Bacill } \\
\text { us } \\
\text { cereus } \\
*\end{array}$ & $\begin{array}{c}\text { Campylobac } \\
\text { ter jejuni }\end{array}$ & $\begin{array}{c}\text { Listeria } \\
\text { monocytogen } \\
e^{*}\end{array}$ & $\begin{array}{c}\text { Streptococc } \\
\text { us } \\
\text { pyogenes* }\end{array}$ & $\begin{array}{c}\text { Methicillin } \\
\text { resistant } \\
\text { Staphylococ } \\
\text { cus aureus }^{* *}\end{array}$ \\
\hline $\begin{array}{l}\text { Emblica } \\
\text { Officina } \\
\quad l e\end{array}$ & $\begin{array}{c}18.00^{b} \pm \\
1.15\end{array}$ & $\begin{array}{c}19.33^{\mathrm{b}} \\
\pm 0.33\end{array}$ & $\begin{array}{c}13.33^{\mathrm{b}} \\
\pm 0.33\end{array}$ & $\begin{array}{c}14.00 \\
\mathrm{~b} \\
\pm 1.15\end{array}$ & $\begin{array}{c}13.00 \pm \\
0.58\end{array}$ & $16.67^{b} \pm 2.33$ & $\begin{array}{c}12.00^{\mathrm{b}} \pm \\
0.00\end{array}$ & $\begin{array}{c}13.00^{c} \pm \\
0.57\end{array}$ \\
\hline $\begin{array}{l}\text { Curcum } \\
\text { a longa }\end{array}$ & $\begin{array}{c}21.00 \\
\mathrm{ab}_{ \pm} \pm 2.31\end{array}$ & $\begin{array}{c}25.00^{\mathrm{ab}} \\
\pm 2.88\end{array}$ & $\begin{array}{l}22.00 \\
\mathrm{ab}_{ \pm} \pm 3.46\end{array}$ & $\begin{array}{c}12.00 \\
\mathrm{~b} \\
\pm 1.15\end{array}$ & $13.00 \pm 0.58$ & $21.00^{\mathrm{ab}} \pm 1.73$ & $\begin{array}{c}18.00 \\
\mathrm{ab}_{ \pm} 2.31\end{array}$ & $\begin{array}{c}18.66^{\mathrm{b}} \\
\pm 0.68\end{array}$ \\
\hline $\begin{array}{c}\text { Gingibe } \\
\quad r \\
\text { Officina } \\
\quad l e \\
\end{array}$ & $\begin{array}{l}26.00^{\mathrm{a}} \\
\pm 1.15\end{array}$ & $\begin{array}{l}30.67^{\mathrm{a}} \\
\pm 3.48\end{array}$ & $\begin{array}{l}24.33^{\mathrm{a}} \\
\pm 3.48\end{array}$ & $\begin{array}{l}18.00^{\mathrm{a}} \\
\pm 1.15\end{array}$ & $13.00 \pm 1.15$ & $25.00^{\mathrm{a}} \pm 1.15$ & $\begin{array}{c}20.33^{\mathrm{a}} \pm \\
4.09\end{array}$ & $\begin{array}{c}22.67^{\mathrm{a}} \pm \\
1.21\end{array}$ \\
\hline
\end{tabular}




\begin{tabular}{|c|l|l|l|}
\hline \multirow{2}{*}{ Name of the herb } & \multicolumn{2}{|c|}{ Properties identified } & Anti bacterial \\
\cline { 2 - 4 } & Antioxidant & Anti viral & 5 \\
\hline Black mustard & 4 & 4 & -- \\
\hline Clove & 3 & -- & 20 \\
\hline Coriander & 7 & 12 & 11 \\
\hline Cumin & 5 & 7 & 13 \\
\hline Garlic & 9 & 5 & 17 \\
\hline Ginger & 6 & 6 & 19 \\
\hline Oregeno & 14 & 11 & 5 \\
\hline Thyme & 4 & 3 & 5 \\
\hline Turmeric & 3 & 3 & \\
\hline
\end{tabular}

Some of the phytogenic feed additives with number of active principles identified

\section{Antioxidant property}

The extracts from the phytogenic plants (herbs \& spices) are said to have Anti-oxidative properties (Wei and Shibamoto, 2007). Among a variety of plants the volatile oils from the Labiatae family have drawn more interest. These anti oxidant feed additives will prevent the auto oxidation of the cells preventing the cell damage and (Miguel,2010) protects the feed lipids also from cell damage. It was reported that these feed additives protect the cells on par with the feed added antioxidants like tocopheryl acetate or butylated hydroxytoluene (BHT).

\section{Some information on herbal residues}

Herbal residues are the left over remained after the active principle is extracted which is the most common method of getting out the active principle. Generally the organizers follow 2 methods of extraction-(i) until equilibrium exists between drug components and solvent (decoctions, tinctures etc) (ii) extraction of active principle to exhaustion (until all solvent extractables are removed. Extraction efficiency $(\%)$ for different methods range from 88-97 and in no case extraction is percent (Chemiloids Pvt Ltd).

Residues of Curcuma longa, Emblicaofficinale and Gingeberisofficinalewere able to inhibitthe pathogenic bacteria Viz- Escherichia coli, Staphylococcus aureus, Salmonella typhimurium, Bacillus cereus, Campylobacter jejuni, Listeria monocytogenes, Streptococcus pyogenes, Methicillin resistant Staphylococcus aureu . These residues were able to inhibit the pathogenic bacteria at $2 \%$ level during the studies by Minimum Inhibitory Concentration (MIC) tests (Suryanarayana, 2010). Feeding diets containing herbal residues reduced $(\mathrm{P}<0.01)$ the Coliform, Staphylococci and Salmonella in the gut of swine (Suryanarayana et al, 2010)

During in vitro studies conducted by (Suryanarayana et al, 2010) it was reported that Zingiberis residue was effective in inhibiting the growth of pathogens. It was observed that herbal residues are able to check the growth of bacteria during fermentation. Higher Organic matter fermentation, higher acetic acid production, lower $\mathrm{pH}$ could be the probable reasons for a lower bacterial count in $\mathrm{T}_{4}$, since these factors can arrest the growth of undesirable bacteria especially Salmonella. It is well known that the presence of the SCFA will lead to a drop in $\mathrm{pH}$ that can have a negative effect on some potentially pathogenic bacteria (Williams et al., 2005). It has also been shown that SCFA inhibit the growth of Salmonella (Van derwiele, 2001). VFA can have an antibacterial effect, thereby preventing the establishment of pathogenic bacteria, such as Salmonella spp. (Cummings and Englyst, 1987).

The growth of Salmonella, a gram-negative bacterium and more dreadful communicable from humans to animals and vice-versa is checked with certain of the Phytogenic feed additives as mentioned here under...

Extract of Schezandra efluctus is effective against 13 strains of Salmonella (Zaika, 1988)

Golden seal fights against harmful bacteria especially Salmonella

Allian, (from garlic oil) checks Salmonella (Johnson and Vanght, 1969)

Turmeric (Curcuma Longa) contains curcuma and curcuminoids (phytochemicals) guard the stomach by killing salmonella (Vitaminstuff.com)

(Windisch et al., 2008) In vitro studies have shown that Ginger extract $(2000 \mathrm{mg} / \mathrm{ml})$ inhibits E. coli, Proteus spp. Staphylococcus, Streptococcus and Salmonella.

Emblica officinalis (active principle) inhibits pathogenic bacteria Coliforms, Staphylococcus and Salmonella in gut of monogastric animals (Bandyopadhyay et al., 2000)

Ginger residue inhibits pathogenic bacteria in the gut followed by turmeric and amla suggesting that ginger has high antibacterial activity (Suryanarayana et al., 2010). These check Coliforms, Staphylococcus and Salmonella In general phytogenic feed additives (herbs and their products) have a strong antibacterial and antifungal properties. They inhibit E. coli. Proteus spp., Staphylococcus, Streptococcus and Salmonella.

\section{CONCLUSION}

The primary mode of action of phytogenic feed additives is by beneficially affecting the ecosystem of GI tract through controlling the pathogens. This is benefitted to the animal during stress conditions by not losing the 
immunity which otherwise usually occurs. There seems no restriction globally over the use of these phytogenic feed additives with a notion that some resistance will develop for them in the animal body

Even though a product is said to be of natural origin, it is not necessarily better or safer than antibiotics or other synthetic feed additives. It is important to note that various antibiotics also are of natural origin. The fact that some herbs and spices also exhibit antimicrobial properties suggests that phytogenic feed additives may pose similar risks to producers and meat consumers. Similarly, potential overdose that may be harmful to the pig also is possible. All of these considerations warrant further investigation into the safety of phytogenic feed additives both for humans and animals.

PFA should not only look to the profitability and superior quality of livestock products but also should look to food safety and environmental regulation. PFA was said to have reduce the environmental pollution by reducing the release of ammonia, methane and greenhouse gas emission. PFA include essential oils, spices, herbs and then products which improves growth rate, nutrient digestibility and gut health in animals. They can act as an alternate to AGP and the rapid growth of the popularity of organic farming can also considered as the major cause for exploring PFA. In a nut shell, PFA increases feed intake, improves gut function, reduces anti-oxidation of the cell and eliminates pathogens from the gut.

\section{REFERENCES}

[1] Anderson D B, McCracken VJ, Aminov RI, Simpson JM, Roderick IM, Verstegen MWA and Gaskins H R (1999) Gut microbiology and growth-promoting antibiotics in swine. Pig News and Information20: $115 \mathrm{~N}-122 \mathrm{~N}$.

[2] Aruoma O I, Spencer J P, Rossi R, Aeschbach R, Khan A, Mahmood N, Munoz A, Murcia A, Butler J and Halliwell B (1996) An evaluation of the antioxidant and antiviral action of extracts of rosemary and Provencal herbs. Food Chemistry and Toxicology 34: 449-456.

[3] Bandyopadhyay S K, Pakrashi S C, Pakrashi A (2000) The role of anti oxidant activity of Phyllanthusemblica fruits on prevention from indomethacin induced gastric ulcer. Journal of Ethnopharmacology 70: 171-176.

[4] Baratta MT, Dorman HJD, Deans SG, Biondi DM, Ruberto G (1998) Chemical composition, antimicrobial and antioxidative activity of laurel, sage, rosemary, oregano and coriander essential oils. J Essent Oil Res.10:618-627.
[5] Benencia F and Courreges M C (2000) In vitro and in vivo activity of eugenol on human herpesvirus. Phytotherapy Research14: 495-500.

[6] Boyaka P N, Marinaro M, Jackson R J, van Ginkel F W, Cormet-Boyaka E, Kirk K L, Kensil C R and McGhee J R (2001) Oral QS-21 requires early IL-4 help for induction of mucosal and systemic immunity. Journal of Immunology 166: 2283-2290.

[7] Chattopadhyay D, Arunachalam G, Ghosh L, Rajendran K, Mandal AB, Bhattacharya SK (2005) Antipyreticactivity of Alstoniamacrophylla Wall ex A. DC: an ethnomedicine of Andaman Islands. Journal of Pharmaceutical Science, 8:558-564

[8] Cowan MM (1999) Plant products as antimicrobial agents. Clin Microbiol Rev 12:564-582

[9] Cummings JH, Englyst HN (1987) Fermentation in the human large intestine and the available substrates. American Journal of Clinical Nutrition, 45: 12431255.

[10]Dorman HJ and Deans SG (2000) Antimicrobial agents from plants: antibacterial activity of plant volatile oils. Journal of Applied Microbiology, 88: 308-316.

[11]Force M, Sparks WS and Ronzio RA (2000) Inhibition of enteric parasites by emulsified oil of oregano in vivo. Phytotherapy Research, 14: 213214.

[12] Garcia CC, Talarico L, Almeida N, Colombres S, Duschatzky C and Damonte EB (2003) Virucidal activity of essential oils from aromatic plants of San Luis, Argentina. Phytotherapy Research17: 10731075.

[13] Guo FC, Kwakkel RP, Williams BA, Parmentier HK, Lis WK, Yang ZQ, Verstegen MWA(2004b). Effects ofmushroom and herb polysaccharides on cellular and humoral immune responses of Emeriatenellainfactedchickens.Poultry Science 83:1124-1132.

[14] Guo FC, Williams BA, Kwakkel RP, Li HS, Li XP, Luo JY, Li WK, Verstegen MW (2004a) Effects ofmushroom and herb polysaccharides, as alternatives for an antibiotic, on the caecal microbial ecosystemin broiler chickens. Poultry Science 83:175-182.

[15]Hashemi SR, Zulkifli I, Hair-Bejo M, Karami M, Soleimani AF (2009a) The effects of Euphorbia hirtaandacidifier supplementation on growth performance and antioxidant activity in broiler chickens. In:Proceedings of the 21st Veterinary Association Malaysia (VAM) Congress, 7-9 August, Port Dickson,Malaysia. pp: 215-217.

[16] Hashemi SR, Zulkifli I, Zunita Z, Hair-Bejo M, Loh TC, Somchit MN, Kok PC, Davoodi H (2009b) Effectsof dietary supplementation with Euphorbia 
hirta and acidifier on performance and Salmonellacolonization in broiler chickens. In: Proceedings of the 30th Malaysia Society of Animal ProductionAnnual Conference, 2-5 June, Kota Kinabalu, Malaysia. pp: 69-70.

[17] Johnson GM, Vaughn RH (1969) Death of Salmonella typhimurium and E.coli in the presence of freshly reconstituted dehydrated garlic and onion. Journal of applied microbiology, Vol.17:903-905.

[18] Jugl-Chizzola M, Spergser J, Schilcher F, Novak J, Bucher A, Gabler C, Hagmuller W, Zitterl-Eglseer K (2005) Effects of Thymus vulgaris $L$. as feed additivein piglets and against haemolytic E. coli in vitro. Berliner und Munchener TierarztlicheWochenschrift.118:495-501.

[19] Mahmoud AL (1994) Antifungal action and antiaflatoxigenic properties of some essential oil constituents. Letters in Applied Microbiology19: 110113.

[20] Managing gut health.Natural growth promoters as a key to animal performance.Nottingham University Press, Nottingham, UK.

[21] Miguel MG (2010) Antioxidant and antiinflammatory activities of essential oils: a short review. Molecules. 15:9252-9287.

[22] Mohammadi

Gheisar M, Hosseindoust A, Kim IH (2015a) Evaluat ing the effect of microencapsulated blends of organic acids and essential oils in broiler chickens diet. Journal of Applied Poultry Research 24:511-519.

[23] MohammadiGheisar M, Im YM, Lee HH, Choi YI, K im IH (2015 b) Inclusion of phytogenic blends in different nutrient density diets of meat-type ducks. Poultry Science 94:2952-2958.

[24] Namkung H, Li M, Gong J, Yu H, Cottrill M, de Lange CFM (2004) Impact of feeding blends of organic acids and herbal extracts on growth performance, gut microbiota and digestive function in newly weaned pigs. Canadian Journal of Animal Science. 84:697-704.

[25] Newbold CJ, McIntosh FM, Williams P, Losa R and Wallance RJ (2004) Effects of a specific blend of essentials oil compounds on rumen fermentation. Animal Feed Science Technology114: 105-112.

[26] Newman DJ, Cragg GM, Snader KM (1999) The influence of natural products upon drug discovery. Nat Prod Rep. 2000; 17:215-234. 20. Cowan MM. Plant products as antimicrobial agents. Clinical Microbiological Review 12:564-582.

[27] Platel K and Srivasan K (2000) Influence of dietary spices and their active principles on pancreatic digestive enzymes in albino rats.Nahrung 44: 42-46.
[28] Regulation (EC) No 1831/2003 of the European Parliament and of the council of $22^{\text {nd }}$ September 2003 on additives for use in animal nutrition. Official Journal of the European Union. 268:29-43.

[29] Sai Ram M, Neetu D, Yogesh B, Anju B, Dipti P, Pauline T, Sharma SK, Sarada SKS, Ilavazhagan G, Kumar, Devendra and Selvamurthy W (2002) Cyto protective and immuno modulating properties of Amla (Emblicaofficinalis) on lymphocytes :an in vitro study. Journal of Ethnopharmacology81: 5-10.

[30] Sakagami Y, Murata H, Tsutomu N, Inatomi Y, Watabe K, Inuma M, Tanaka T, Murata J and Lang FA (2001) Inhibitory effect of plant extracts on production of verotoxin by enterohemorrhagic Escherichia coli O 157:H7. Journal of Health Science 47: 473-477.

[31]Steiner T (2009) Phytogenic in animal nutrition.Natural concepts to optimize gut health and performance.1st Ed. Nottingham University Press, Nottingham, p 181.

[32] Steiner $\mathrm{T}$ andSternJL(2006) Assess potential fermentability of feed ingredients for monogastric diets. Animal Feed Science, Hagerman P D, Steinberg P D and Mason PK 1996 Phlorotannin-protein interactions. Journal of Chemical Ecology 22: 18871899.

[33] Stern JL, Hagerman PD, Steinberg PD and Mason PK (1996) Phlorotannin-protein interactions. Journal of Chemical Ecology 22: 1887-1899.

[34] Sulabo RC, Jacela JY, DeRouchey JM, Tokach MD, Neher F, GoodbandRD, Dritz SS, Nelssen JL (2007) Effects of phytobiotics (BIOMIN® P.E.P.) onnursery pig performance.Kansas AgricExpStaProg Rep 985: 94-98.Available at: http://asi.ksu.edu/DesktopModules/ViewDocument.a spx?DocumentID=4583. Accessed 25 March 2010.

[35] Suryanarayana, MVAN, Ravi A, Ramana JV, Sudhakar Reddy P and Eswar Prasad P(2010) A study on the effect of enzymes and herbal residues on the performance, nutrient utilization and carcass characteristics of cross-bred pigs. Ph. D., thesis submitted to Sri Venkateswara Veterinary University, Tirupati.

[36] Teissedre PL and Waterhouse AL (2000) Inhibition of oxidation of human low-density lipoproteins by phenolic substraces in different essential oils varieties. Journal of Agriculture and Food Chemistry 48: 3801-3805.

[37] Tsuchiya H, Sato M, Miyazzaki T, Fujiwara S, Tanigaki S, Ohyama M, Tanaka $\mathrm{T}$ and Iinuma $\mathrm{M}$ (1996) Comparative study on the antibacterial activity of phytochemical flavanones against 
methicillin-resistant Staphylococcus aureus. Journal of Ethnopharmacology50: 27-34.

[38] Van der Meulen J, Inborr J and Bakker JGM (2001) Effects of cell wall degrading enzymes on carbohydrate fractions and metabolites in stomach and ileum of pigs fed wheat bran based diets. Archives of Animal Nutrition.54: 101-115.

[39] Wei A and Shibamoto T (2007) Anti-oxidant activities and volatile constituents of various essential oils. Journal of Agricultural Food Chemistry.55:1737-1742.

[40] Williams BA, Bosch MW, Boer H, Verstegen MWA and TammingaS (2005) An in vitro batch culture method to assess potential fermentability feed ingredients for monogastric diets. Animal feed science and Technology. 123-124: 445-462.

[41] Windisch W, Schedle K, Plitzner C and Kroismayr A (2008) Use of phytogenic feed additives foe swine and poultry.Journal of Animal Science 86: E 140E148.

[42]Zaika LL (1988) Spices and herbs: their antimicrobial activity and its determination. Journal of Food Safety,9 (2): 97-118.

[43]Zhang $Y$ and Lewis K (1997) Fabatins: new antimicrobial plant peptides. FEMS Microbiology Letters 149: 59-64. 